\title{
ANALISIS PELAKSANAAN PROSEDUR OPERASIONAL STANDAR SARANA DAN PRASARANA BELAJAR LABORATORIUM BERDASARKAN MANAJEMEN MUTU ISO 9001:2008 \& IWA 2:2007 DI JURUSAN TEKNIK SIPIL UNIVERSITAS NEGERI JAKARTA
}

\author{
Ricki Dwi Agusti ${ }^{1}$, Santoso Sri Handoyo ${ }^{2 *}$, Sittati Musalamah ${ }^{3 *}$ \\ ${ }^{1}$ Alumni Pendidikan Teknik Bangunan FT UNJ,Jakarta, Indonesia. \\ 2 Pendidikan Teknik Bangunan, FT UNJ, Jakarta, Indonesia. \\ 3 Pendidikan Teknik Bangunan, FT UNJ, Jakarta, Indonesia \\ *Corresponding author: santoso_handoyo@unj.ac.id, smusalamah@unj.ac.id
}

\begin{abstract}
The objectives of this study to determine the percentage level implementation of Standard Operating Procedures learning facilities Laboratory of Civil Engineering, State University of Jakarta in the implementation of quality management ISO 9001: 2008 \& IWA 2: 2007. The study lasted for three months from September to November 2013.

Place of research conducted at the State University of Jakarta, precisely at 5 Laboratory of the Laboratory of Wood, Land, Material, Stone, and Plumbing Department of Civil Engineering, State University of Jakarta. The population in this study was 55 Laboratory of Laboratory of Civil Engineering Laboratory UNJ include Wood, Land, Material, Stone, and Plumbing. The method used in this research is survey method with data collection using a questionnaire or questionnaires. The trial questionnaire of 115 statements. The test is done to 7 respondents. After the test phase the results obtained valid instruments as much as 112-point declaration.

Data analysis technique is done by searching percentage. The results show that: (a) Laboratory of Civil Engineering UNJ have a Standard Operating Procedure (POS) especially Infrastructures based quality management standard ISO 9001: 2008 and IWA 2: 2007 (b) There are four (4) POS on Infrastructures Laboratory Civil engineering UNJ whose accomplishments are not up to $100 \%$. which amounted to $64.7 \%$ which can be categorized fulfillment are lacking, (c) Acquired four (4) percentage level of achievement of the implementation of POS Infrastructures Civil Engineering Laboratory UNJ the percentage rate of the unit does not reach $100 \%$. The results are the result of the analysis of data derived from the 5 respondents who are Laboran of 5 laboratories in this study are: Health, Safety and Environment Laboratory (weight percentage of 73.3\%) were categorized been fulfilled, Use of Laboratory (weight percentage of $71 \%$ ) categorized been met, Laboratory Equipment Loan (weight percentage of 66.8\%) categorized as less fulfilled, and the maintenance and care Laboratory (weight percentage of 47.8\%) were categorized are lacking, (d) There is inequality between understanding Laboran percentage of POS by $82,8 \%$ by POS regarding Infrastructures Laboratory of $64.7 \%$.
\end{abstract}

Keywords: Infrastructures Learning Laboratory, Quality Management ISO 9001: 2008 \& IWA 2: 2007.

\section{PENDAHULUAN}


Pendidikan merupakan suatu berkah dari Maha Pencipta terhadap ciptaan-Nya. Manusia merupakan satu-satunya mahkluk yang ditakdirkan untuk memperoleh pendidikan. Pendidikan merupakan upaya mencerdaskan kehidupan bangsa dan merupakan hak seluruh rakyat untuk menuntutnya. Amanah dari dasar negara kita (UUD 1945) diartikan bahwa bangsa cerdas adalah bangsa yang berdiri sendiri, berdikari, dan mandiri. Hal ini diperkuat pada pasal 3 UU No. 23 Tahun 2003 tentang sisten pendidikan nasional, bahwa pendidikan nasional berfungsi mengembangkan kemampuan dan membentuk watak serta peradaban bangsa yang bermartabat dalam rangka mencerdaskan kehidupan bangsa, bertujuan untuk berkembangnya potensi peserta didik agar menjadi manusia yang beriman dan bertakwa kepada Tuhan Yang Maha Esa, berakhlak mulia, sehat, berilmu, cakap, kreatif, mandiri, dan menjadi warga negara yang demokratis serta bertanggung jawab.

Pada saat ini dunia pendidikan di Indonesia mempunyai beberapa permasalahan yang dimana perlu diselesaikan dengan berbagai macam ilmu disiplin tentang pendidikan yang telah ada. Beberapa permasalahan muncul biasanya dari faktor teknis maupun nonteknis, baik dari jenjang sekolah dasar di kelas maupun jenjang mahasiswa di universitas dalam melaksanakan sistem pengajaran maupun kegiatan belajar. Permasalahan tersebut perlu diselesaikan demi mewujudkan tujuan pembelajaran yang berkompeten.

Hal tersebut juga mempengaruhi mutu pendidikan di Indonesia saat ini yag masih memiliki banyak kekurangan dalam proses peningkatan mutu pendidikan yang baik dan berkompeten tinggi. Pendidikan di Indonesia masih kalah baik dengan Pendidikan di luar negeri, terbukti masih banyak warga negara Indonesia yang lebih memilih melanjutkan pendidikannya di luar Indonesia dibandingkan di dalam negeri sendiri. Namun beberapa perbaikan terus dilakukan di setiap jenjang pendidikan yang ada di Indonesia. Salah satunya dengan meningkatkan standar mutu pendidikan dengan standar manajemen mutu internasional. Perbaikan sistem manajemen dalam dunia pendidikan menjadi hal utama yang harus diselesaikan dan ditingkatkan menuju Pendidikan Indonesia yang baik, salah satunya perbaikan sistem manajemen mutu pendidikan di jenjang Universitas.

Demi peningkatan Pelayanan dan mutu pendidikan di Fakultas Teknik Universitas Negeri Jakarta (FT-UNJ) melaksanakan audit eksternal untuk mendapatkan sertifikasi manajemen mutu. Kegiatan audit eksternal di FT-UNJ dilakukan oleh PT. SGS sebagai badan penjaminan mutu. Kegiatan audit eksternal tersebut dilakukan di 10 program studi dan 1 unit kerja yang diaudit, yaitu Pendidikan Teknik Mesin (S1), Teknik Mesin (D3), Pendidikan Teknik Elektro (S1), PTIK (S1), Pendidikan Teknik Bangunan (S1), Teknik Elektronika (D3), Pendidikan Tata Boga (S1), Tata Boga (D3), Pendidikan Tata Busana (S1), Tata Busana (D3), PD 1, dan GPjM. Dan akhirnya pada bulan Mei 2011 memperoleh sertifikat ISO 9001:2008 dan IWA 2:2007. Sampai bulan Mei 2013 PT. SGS masih melaksanakan supervisi 
dalam proses kegiatan pendidikan yang ada di FTUNJ.

ISO 9001: 2008 memiliki 8 prinsip manajemen yang menjiwai dan sebagai panduan bagi manajemen dalam menerapkan standar internasional ini yaitu : pendekatan proses, memahami kompetensi inti (fokus pada pelanggan), optimisasi total (pendekatan sistem terhadap manajemen), kepemimpinan jauh kedepan (kepemimpinan), pendekatan faktual (pendekatan faktual untuk pengambilan keputusan), bekerjasama dengan mitra (hubungan penyedia barang dan jasa yang saling menguntungkan), pelibatan personal, peningkatan berkelanjutan.

IWA 2 :2007 adalah panduan penerapan sistem manajemen mutu ISO 9001:2008 bagi institusi pendidikan. Panduan ini dipublikasikan oleh ISO (the International Organization for Standarization) serta disusun melalui mekanisme workshop, dan bukan melalui proses komite. IWA 2:2007 disetujui melalui konsensus diantara para partisipan. Pada bagian pengenalan dari IWA 2 2007, dinyatakan bahwa ada 4 penambahan prinsip manajemen dalam penerapan system manajemen mutu ISO 9001:2008 pada institusi pendidikan. Empat prinsip tambahan untuk sukses yang berkelanjutan sebagai berikut : Menciptakan siswa bernilai, Memusatkan pada nilai sosial, gesit, otonomi.

Satu hal penting yang harus diperhatikan bahwa IWA 2 merupakan panduan atau pelengkap persyaratan ISO 9001:2008. Jadi tidak boleh sebagai pengganti ISO 9001:2008 dan tidak dapat dijadikan acuan kontrak dalam peninjauan kesesuaian maupun untuk keperluan sertifikasi. Setelah mendapatkan sertifikasi manajemen mutu FT-UNJ juga harus diawasi oleh lembaga sertifikasi SGS Indonesia setiap 6 bulan sekali. Pengawasan dilakukan dalam bentuk audit eksternal yang bertujuan untuk mengkonfirmasi kesesuaian sistem manajemen mutu yang dijalankan oleh FT-UNJ dengan standar ISO 9001:2008 dan IWA 2:2007, mengetahui efektivitas dari implementasi rencana mutu oleh FT-UNJ, dan sasaran mutu dan tujuan yang telah ditetapkan dapat dipenuhi.

Aspek-aspek yang dilihat dalam penilaian standar manajemen mutu diantaranya aspek manajemen, aspek administrasi, aspek akademis, aspek non akademis. Hal ini FT-UNJ telah dipercaya mendapatan sertifikasi manajemen mutu tersebut yang salah satunya adalah dari aspek akademis. Dari aspek akademis, salah satu yang dilihat adalah sarana dan prasarana belajar dalam laboratorium praktek mahasiswa. Teknik Sipil merupakan bagian dari FT-UNJ, maka sudah seharusnya Prosedur Operasional Standar dari manajemen mutu tersebut juga menjadi acuan dan sudah diterapkan di Jurusan Teknik sipil UNJ. Prosedur Operasional Standar untuk mengenai Sarana dan Prasarana Laboratorium meliputi, POS penggunaan ruang kuliah, POS penggunaan laboratorium, POS pemeliharaan kendaraan dinas, POS kesehatan, keselamatan kerja dan lingkungan di laboratorium, POS pemeliharaan dan perawatan Laboratorium, POS pemeliharaan dan perawatan non Laboratorium, POS Pemijaman peralatan 
laboratorium, POS peminjaman alat non laboratorium, POS pengadaan barang, POS pengelolaan protokoler. Dari 10 POS mengenai Sarana dan Prasarana Laboratorium, saya mengambil 4 POS yang akan diteliti yaitu POS penggunaan Laboratorium, POS kesehatan, keselamatan kerja dan lingkungan di laboratorium, POS pemeliharaan dan perawatan laboratorium, dan POS peminjaman peralatan laboratorium. Yang saya pilih dalam penelitian saya adalah Laboratorium Teknik Sipil. Dalam Pelaksanaan dari 4 POS tersebut mungkin ada kekurangan dan kelebihan yang timbul selama ini, serta tidak semua orang di lingkungan jurusan Teknik Sipil mengetahui mengenai Pelaksanaan 4 POS tersebut. Atas dasar tersebut dirasa perlu mengetahui tingkat persentase pelaksanaan Prosedur Operasional Standar dari manajemen mutu ISO 9001:2008 \& IWA 2:2007 Laboratorium Teknik Sipil UNJ.

Tujuan pengambilan judul tersebut adalah ingin mengetahui sejauh mana kesesuaian kondisi aktual Prosedur Operasional Standar dari Standar Manajemen Mutu ISO 9001:2008 \& IWA 2:2007 yang diterapkan dalam laboratorium Teknik Sipil UNJ jika ditinjau dari sarana dan prasarana yang ada, maksud dari penelitian ini adalah mengetahui kekurangan atau kelebihan yang ada dalam laboratorium tersebut sehingga ke depannya dapat dibuat pertimbangan dalam peningkatan standarisasi manajemen mutu yang berlaku saat ini.

\section{Pengertian Sarana \& Prasarana Pendidikan}

Sarana adalah segala sesuatu yang dapat dipakai sebagai alat dalam mencapai maksud. Menurut Mulyasa (2004) "Sarana pendidikan adalah peralatan dan perlengkapan yang secara langsung dipergunakan dan menunjang proses pendidikan, khususnya proses belajar, mengajar, seperti gedung, ruang kelas, meja kursi, serta alatalat dan media pengajaran".

Pengertian prasarana secara etimologis (arti kata) prasarana berarti alat tidak langsung untuk mencapai tujuan. Dalam pendidikan misalnya : lokasi/tempat, bangunan sekolah, lapangan olah raga, uang dan sebagainya. Sedang sarana seperti alat langsung untuk mencapai tujuan pendidikan, misalnya : ruang, buku, perpustakaan, laboratorium dan sebagainya.

Secara umum sarana dan prasarana pendidikan adalah alat penunjang keberhasilan suatu proses pendidikan, upaya yang dilakukan di dalam pelayanan publik, karena apabila kedua hal ini tidak tersedia maka semua kegiatan yang dilakukan tidak akan dapat mencapai hasil yang diharapkan sesuai dengan rencana.

\section{Pengertian Manajemen Mutu}

Manajemen mutu adalah gabungan semua fungsi manajemen, semua bagian dari suatu perusahaan dan semua orang ke dalam falsafah holistik yang dibangun berdasarkan konsep kualitas, teamwork, produktivitas, dan kepuasan pelanggan (Nasution. 2001). Definisi lainnya mengatakan bahwa manajemen mutu merupakan sistem manajemen yang mengangkat kualitas sebagai strategi usaha dan berorientasi pada 
kepuasan pelanggan dengan melibatkan seluruh anggota organisasi. Manajemen mutu merupakan sistem manajemen yang berfokus pada pada orang/ karyawan.

\section{Manajemen Mutu ISO 9001 \& IWA 2 : 2007}

Manajemen Mutu ISO 9001:2008 Merupakan prosedur terdokumentasi dan praktek praktek standar untuk manajemen sistem, yang bertujuan menjamin kesesuaian dari suatu proses dan produk (barang atau jasa) terhadap kebutuhan atau persyaratan tertentu, dimana kebutuhan atau persyaratan tertentu tersebut ditentukan atau dispesifikasikan oleh pelanggan dan organisasi.

IWA-2 : 2007 adalah panduan penerapan Sistem Manajemen Mutu (SMM) ISO 9001 bagi lembaga pendidikan. IWA adalah singkatan dari International Workshop Agreement. Panduan ini dipublikasikan oleh ISO (International Organization for Standardization) serta disusun melalui mekanisme workshop, dan bukan melalui proses komite.International Workshop Agreement disetujui melalui konsensus diantara para partisipan. Panduan ini ditinjau setiap 3 tahun untuk memastikan kesesuaiannya dengan standar sistem manajemen mutu yang berlaku. Berdasarkan hasil dari tinjauan maka diputuskan apakah panduan ini akan direvisi atau ditarik.

\section{Prosedur Operasional Standar}

Prosedur Operasional Standar adalah suatu set instruksi yang memiliki kekuatan sebagai suatu petunjuk atau direktif. Hal ini mencakup hal-hal dari operasi yang memiliki suatu prosedur pasti atau terstandardisasi, tanpa kehilangan keefektifannya. Setiap sistem manajemen kualitas yang baik selalu didasari oleh POS. Pentingnya POS pada seluruh proses penyelenggaraan administrasi. Hal ini dinilai penting karena Prosedur Operasional Standar adalah pedoman atau acuan untuk melaksanakan tugas pekerjaan sesuai dengan fungsi dan POS juga merupakan alat penilaian kinerja instansi berdasarkan indikator indikator teknis, administrasif dan prosedural sesuai dengan tata kerja, prosedur dan sistem kerja pada unit kerja yang bersangkutan.

\section{METODE PENELITIAN}

Penelitian ini dilakukan di Universitas Negeri Jakarta tepatnya di 5 Laboratorium yaitu Laboratorium Kayu, Tanah, Bahan, Batu, dan Plumbing Jurusan Teknik Sipil Universitas Negeri Jakarta. Waktu penelitian akan dilaksanakan pada bulan September -November 2013.

Metode penelitian adalah suatu cara atau prosedur yang dipergunakan untuk melakukan penelitian sehingga mampu menjawab rumusan masalah dan tujuan penelitian. Menurut Sugiyono (2011) Metode penelitian merupakan cara ilmiah untuk mendapatkan data dengan tujuan dan kegunaan tertentu. Metode penelitian pada dasarnya merupakan cara ilmiah untuk mengumpulkan data dengan tujuan dan kegunaan tertentu. Cara ilmiah berarti kegiatan penelitian itu didasarkan pada ciri-ciri keilmuan yaitu rasional, empiris dan sistematis. Metode yang digunakan 
dalam penelitian ini adalah metode survey dengan pengumpulan data menggunakan angket atau kuisioner. Kuisioner adalah instrumen penelitian yang berupa daftar pertanyaan untuk memperoleh keterangan dari sejumlah responden (sumber yang diambil datanya melalui angket). Angket atau kuesioner dapat disebut sebagai wawancara tertulis, karena isi kuesioner merupakan satu rangkaian pertanyaan tertulis yang ditujukan kepada responden dan diisi sendiri oleh responden

Karena jumlah populasi dalam penelitian ini kurang dari 100 responden dan berjumlah 5 responden, maka populasi dalam penelitian ini adalah 5 Laboran dari 5 Laboratorium Teknik Sipil UNJ meliputi Laboratorium Kayu, Tanah, Bahan, Batu, dan Plumbing.

Dalam penelitian ini tidak ada batasan sampel yang digunakan karena jumkah populasi yang ada dibawah 100 responden, maka dari itu 5 responden digunakan dalam teknik pengambilan sampel dalam penelitian ini. Teknik pengumpulan data yang akan dilakukan pada penelitian ini adalah dengan kuesioner. Jenis metode kuesioner dalam penelitian ini adalah kuesioner tertutup dimana sudah disediakan jawabannya sehingga responden tinggal memilih.

Uji Coba Instrumen

Setelah seluruh data diperoleh melalui dan kuisioner terkumpul, kemudian dilakuakan tahap berikutnya, yaitu analisis data. Untuk memperoleh validitas dilakukan dengan pengujian validitas Ahli. Setelah kuisioner diuji validitasnya, maka untuk menentukan rangking dalam setiap penilaian dari responden digunankan analisis persentase ratarata serta ditambahkan hasil wawancara responden, dan analisis dari pakar atau ahli dalam penelitian ini.

Untuk menguji validitas, dapat digunakan pendapat dari ahli (judgment experts). Dalam hal ini setelah instrumen tentang aspek-aspek yang akan diukur dengan berlandaskan teori tertentu, maka selanjutnya dikonsultasikan dengan ahli. Para ahli diminta pendapatnya tentang instrument yang telah disusun itu. Hasil dari validitas oleh para ahli adalah mungkin para ahli akan memberikan keputusan: instrumen dapat digunakan tanpa perbaikan, ada perbaikan, dan mungkin dirombak total (Sugiyono, 2007).

Uji kuisioner kepada ahli adalah penilaian dan penyeleksian kuisioner oleh seorang ahli yang dipilih berdasarkan pengetahuan, dan pengalaman mereka dalam kegiatan praktikum di Laboratorium. Dalam penelitian ini, peneliti menunjuk 7 ahli yang akan menilai dan menyeleksi tiap butir pada kuesioner. Ahli berasal dari tenaga dosen yang memiliki pengalaman dan jam mengajar di Laboratorium Teknik Sipil UNJ. Ketujuh ahli tersebut diharapkan dapan menyeleksi butir-butir analisis faktor yang memang dibutuhkan pada kuisoner untuk nantinya disebar untuk dianalisis

\section{HASIL DAN PEMBAHASAN}

Pada kuesioner tersebut diberikan suatu alternatif jawaban yang disajikan dalam bentuk rangking dari 1 (satu) sampai 4 (empat) yang menunjukan pilihan terbanyak dari hasil kuesioner.

Kuesioner berisi 112 (seratus dua belas)butir 
pernyataan yang dikelompokan dalam berbagai POS untuk memudahkan identifikasinya. Data hasil penyebaran kuesioner dari 5 (lima) responden di 5 (lima) laboratorium teknik sipil UNJ kemudian ditabulasi sehingga dapat diketahui nilai jawaban tiap variabel dari keseluruhan kuesioner.

Setalah didapat data hasil tabulasi kuisioner yang telah tekumpul, maka tahap selanjutnya dilakuan analisis untuk mendapatkan hasil persentase jawaban ataskuisioner yangdi jawab oleh responden dengan menggunakan metode persentase :

a. Melakukan dekomposisiuntuk setiap butir kuesionerdari masing-masing 4 (empat) tingkatanpilihan jawaban (bobot)dari 5 laboratorium untuk setiap butir satuan POS. Penilaian variabel kuesioner dapat dilihat pada lampiran.

b. Menghitung total hasil dari penjumlahan setiap butir kuesioner dari masing-masing 4 (empat) tingkatan pilihan jawaban (bobot) dari 5 laboratorium kemudian dibagi sesuai dengan jumlah butir kuesioner dalam butir satuan POS tersebut lalu dikalikan 100\%. Persentase ini dicari untuk melihat penempatan skala yang telah disediakan terhadap masing-masing butir satuan POS.

c. Setelah menghitung persentase dari butir satuan POS, kemudian hasil dari beberapa persentase dari butir satuan POS dijumlahkan serta dibagi jumlah butir satuan yang tersedia untuk satu POS dan hasil tersebut dapat diklasifikasikan ke skala yang telah disediakan untuk masing-masing POS. Perhitungan persentase total untuk 1 POS dapat diliihat pada lampiran

Berdasarkan pembagian level atau skala dari Manajemen mutu IWA 2 : 2007 tingkat (\%) pemenuhan dikelompokkan berdasarkan kategori dalam tabel sebagai berikut :

Tabel 1. Kategori Tingkat Pemenuhan

\begin{tabular}{|c|c|}
\hline Presentase & Kategori \\
\hline $0 \%-39,9 \%$ & Tidak Terpenuhi \\
\hline $40 \%-69,9 \%$ & Kurang Terpenuhi \\
\hline $70 \%-84,9 \%$ & Terpenuhi \\
\hline $85 \%-100 \%$ & Sangat Terpenuhi \\
\hline
\end{tabular}

Selanjutnya akan disajikan persentase untuk setiap butir satuan POS dalam satu POS mengenai tingkat persentase pelaksanaan POS penggunaan laboratorium.

Tabel 2. Tingkat (\%) Pelaksanaan POS Penggunaan Laboratorium 


\begin{tabular}{|c|l|c|c|}
\hline No & \multicolumn{1}{|c|}{ Butir satuan SOP } & (\%) & Klasifikasi \\
\hline 1 & Surat permohonan penggunaan Laboratorium & $28,7 \%$ & Tidak terpenuhi \\
\hline 2 & Jadwal kegiatan Laboratorium & $82,5 \%$ & Terpenuhi \\
\hline 3 & Tata tertib & $82,0 \%$ & Terpenuhi \\
\hline 4 & Bahan praktikum & $70,0 \%$ & Terpenuhi \\
\hline 5 & Instruksi kerja peralatan & $76,2 \%$ & Terpenuhi \\
\hline 6 & Dosen Pengampu & $85,8 \%$ & Sangat terpenuhi \\
\hline
\end{tabular}

Tabel 3. Tingkat (\%) Pelaksanaan POS Kesehatan, Keselamatan Kerja dan Lingkungan di Laboratorium

\begin{tabular}{|c|l|c|c|}
\hline No & \multicolumn{1}{|c|}{ Butir satuan SOP } & $\mathbf{1} \% \mathbf{~}$ & Klasifikasi \\
\hline 1 & Peraturan & $87,5 \%$ & Sangat terpenuhi \\
\hline 2 & $\begin{array}{l}\text { Buku kegiatan Praktikum dan Buku petunjuk/Manual } \\
\text { alat }\end{array}$ & $71,0 \%$ & Terpenuhi \\
\hline 3 & Pelindung mesin \& bahan Laboratorium & $59,3 \%$ & Kurang terpenuhi \\
\hline 4 & Marka pada Laboratorium & $49,4 \%$ & Kurang terpenuhi \\
\hline 5 & Pakaian kerja dan alat keselamatan kerja & $87,5 \%$ & Sangat terpenuhi \\
\hline 6 & Sanksi & $85,0 \%$ & Sangat terpenuhi \\
\hline
\end{tabular}

Tabel 4. Tingkat (\%) Pelaksanaan POS Pemeliharaan dan Perawatan Laboratorium

\begin{tabular}{|c|l|c|c|}
\hline No & \multicolumn{1}{|c|}{ Butir satuan SOP } & (\%) & Klasifikasi \\
\hline 1 & $\begin{array}{l}\text { Daftar jenis pekerjaan perawatan Laboratorium dan } \\
\text { alat Laboratorium }\end{array}$ & $25,0 \%$ & Tidak terpenuhi \\
\hline 2 & Jadwal kegiatan perawatan umum Laboratorium & $35,0 \%$ & Tidak terpenuhi \\
\hline 3 & $\begin{array}{l}\text { Tugas Laboran sebelum pelaksanaan kegiatan } \\
\text { praktikum }\end{array}$ & $62,5 \%$ & Kurang terpenuhi \\
\hline 4 & $\begin{array}{l}\text { Tugas Laboran selama pelaksanaan kegiatan } \\
\text { praktikum }\end{array}$ & $63,0 \%$ & Kurang terpenuhi \\
\hline 5 & $\begin{array}{l}\text { Tugas Laboran setelah pelaksanaan kegiatan } \\
\text { praktikum }\end{array}$ & $51,2 \%$ & Kurang terpenuhi \\
\hline 6 & Prosedur perawatan yang dilaksanakan oleh praktikan & $50,0 \%$ & Kurang terpenuhi \\
\hline
\end{tabular}


Tabel 5. Tingkat (\%) Pelaksanaan POS Peminjaman Peralatan Laboratorium

\begin{tabular}{|c|l|c|c|}
\hline No & \multicolumn{1}{|c|}{ Butir satuan SOP } & $(\mathbf{\%})$ & Klasifikasi \\
\hline 1 & Peminjaman & $84,5 \%$ & Terpenuhi \\
\hline 2 & Pengembalian & $65,0 \%$ & Kurang terpenuhi \\
\hline 3 & Penggantian alat yang rusak/hilang & $51,0 \%$ & Kurang terpenuhi \\
\hline
\end{tabular}

Dari perhitungan persentase pelaksanaan untuk setiap satuan butir POS dalam 1 POS, didapat persentase total untuk 1 POS sebagai berikut :

Tabel 6. Bobot Persentase Total untuk Setiap 1 POS

\begin{tabular}{|c|l|c|}
\hline No & \multicolumn{1}{|c|}{ SOP } & Tingkat (\%) \\
\hline 1 & Penggunaan Laboratorium & $71,0 \%$ \\
\hline 2 & Kesehatan, Keselamatan Kerja dan Lingkungan di Laboratorium & $73,3 \%$ \\
\hline 3 & Pemeliharaan dan perawatan Laboratorium & $47,8 \%$ \\
\hline 4 & Peminjaman Peralatan Laboratorium & $66,8 \%$ \\
\hline
\end{tabular}

Total perhitungan dari semua butir hasil analisa kuantitatif untuk tingkat persentase

kuisioner dapat dilihat pada lampiran. Hasil proses

pelaksanaan POS Sarana dan Prasarana

pembobotan untuk masing-masing butir kuesioner

Laboratorium Teknik Sipil berdasarkan manajemen dapat diurutkan dari nilai yang terbesar sampai mutu ISO 9001:2008 \& IWA 2 :2007 dari yang terkecil. Pada gambar di bawah ini diperlihatkan tertinggi sampai yang terendah persentasenya

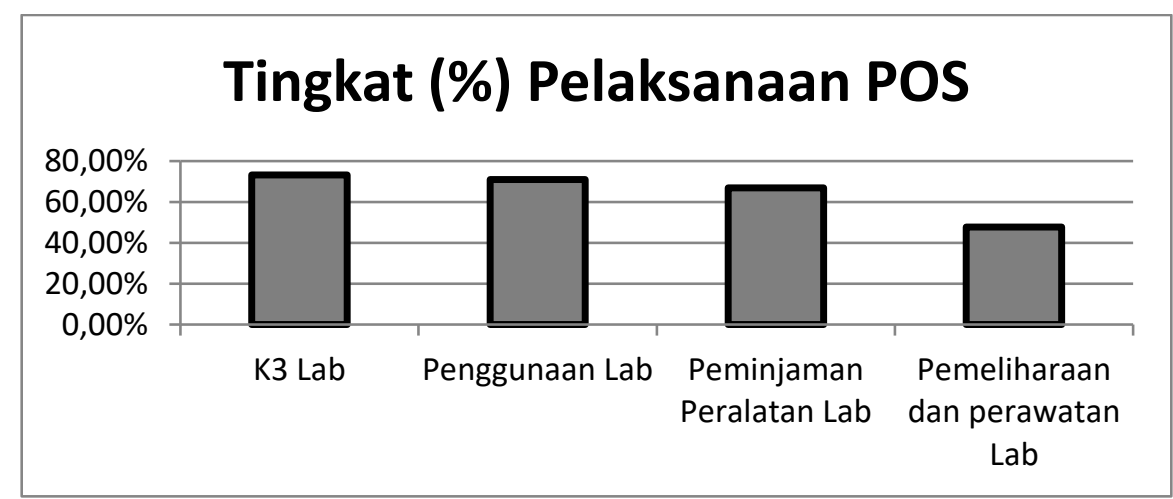

Gambar 1. Persentase Tingkat Pelaksanaan POS 
Pemahaman Laboran tentang Prosedur

Operasional Standar Laboratorium juga merupakan bagian penting dalam keseluruhan pelaksanaan pencapaian pemenuhan Prosedur Operasional Standar khususnya Sarana dan Prasarana Laboratorium Teknik Sipil UNJ berdasarkan manajemen mutu ISO 9001:2008 \& IWA
2:2007. Untuk menunjang hasil persentase total mengenai Prosedur Operasional Standar maka dibuat butir-butir kuesioner khusus untuk mengetahui mutu kinerja dari 5 Laboran untuk 5 Laboratorium yang ada di Teknik Sipil UNJ. Dari 7 butir kuesioner yang diberikan, hasilnya sebagai berikut :

Tabel 7. Bobot Persentase Kuesioner Pemahaman Laboran tentang POS Laboratorium

\begin{tabular}{|c|c|c|}
\hline No & Pernyataan & Rata-rata Nilai \\
\hline 1 & $\begin{array}{l}\text { Apakah data lengkap mengenai Prosedur Operasional } \\
\text { Standar Laboratorium yang dimiliki oleh Laboran sudah } \\
\text { terpenuhi? }\end{array}$ & 3,4 \\
\hline 2 & $\begin{array}{l}\text { Apakah pengetahuan Laboran mengenai informasi } \\
\text { tentang Prosedur Operasional Standar Laboratorium } \\
\text { sudah terpenuhi? }\end{array}$ & 1,8 \\
\hline 3 & $\begin{array}{l}\text { Apakah kehadiran Laboran setiap harinya sudah } \\
\text { terpenuhi? }\end{array}$ & 4 \\
\hline 4 & $\begin{array}{l}\text { Apakah Ketepatan waktu kehadiran Laboran setiap } \\
\text { harinya sudah terpenuhi? }\end{array}$ & 3,8 \\
\hline 5 & $\begin{array}{l}\text { Apakah Ketepatan waktu pulang Laboran setaip harinya } \\
\text { sudah terpenuhi? }\end{array}$ & 3,8 \\
\hline 6 & $\begin{array}{l}\text { Apakah Laporan yang dibuat Laboran mengenai } \\
\text { kehadiran untuk setiap harinya sudah terpenuhi? }\end{array}$ & 4 \\
\hline 7 & $\begin{array}{l}\text { Apakah Pelaksanaan Prosedur Operasional Standar } \\
\text { Laboratorium tersebut sudah terpenuhi? }\end{array}$ & 2,4 \\
\hline & Jumlah & $23,2 / 28 \times 100 \%=82,8 \%$ \\
\hline
\end{tabular}

Hasil persentase total mengenai dikategorikan cukup terpenuhi, namun dengan Pemahaman Laboran tentang POS hal ini terjadi ketimpangan persentase Laboratorium adalah $82,8 \%$ yang dapat mengenai 4 POS yang ada di dalam 
Laboratorium Teknik Sipil UNJ. Dari 4 POS yang ada, terdapat 2 persentase pelaksanaan yang cukup timpang dengan persentase total mengenai pemahaman Laboran yaitu POS mengenai Peminjaman Peralatan Laboratorium $66,8 \%$ dan POS mengenai Pemeliharaan dan perawatan Laboratorium dan Alat 47,8\%. Dengan hasil tersebut menunjukkan adanya masalah yang terjadi di dalam kinerja Laboran untuk pelaksanaan POS khususnya Sarana dan Prasarana Teknik Sipil UNJ berdasarkan manajemen mutu IS0 9001:2008 \& IWA 2:2007. Jadi, Persentase akhir dari 4 POS yang harus dipenuhi oleh 5 Laboratorium adalah $64,7 \%$ yang dapat dikategorikan pencapaian pemenuhannya kurang terpenuhi.

\section{KESIMPULAN}

Berdasarkan deskripsi, analisis, dan interpretasi data yang telah diuraikan pada babbab sebelumnya, dapat ditarik kesimpulan sebagai berikut :

1. Laboratorium Teknik Sipil UNJ memiliki POS khususnya Sarana dan Prasarana berdasarkan standar manajemen mutu ISO 9001:2008 dan IWA 2:2007.

2. Ada 4 (empat) POS mengenai Sarana dan Prasarana Laboratorium Teknik Sipil UNJ yang pencapaiannya tidak sampai $100 \%$. yaitu sebesar $64,7 \%$ yang dapat dikategorikan pemenuhannya kurang terpenuhi.

3. 4 (empat) tingkat persentase dari pencapaian pemenuhan POS Sarana dan Prasarana Laboratorium Teknik Sipil UNJ tersebut merupakan hasil dari analisis data yang berasal dari 5 responden yang merupakan Laboran dari 5 Laboratorium pada penelitian ini adalah :

a. Kesehatan, Keselamatan Kerja dan Lingkungan di Laboratorium (bobot persentase $73,3 \%$ ) dikategorikan sudah terpenuhi.

b. Penggunaan Laboratorium (bobot persentase $71 \%$ ) dikategorikan sudah terpenuhi.

c. Peminjaman Peralatan Laboratorium (bobot persentase 66,8\%) dikategorikan kurang terpenuhi.

d. Pemeliharaan dan perawatan Laboratorium (bobot persentase $47,8 \%$ dikategorikan kurang terpenuhi.

4. Terdapat ketimpangan persentase antara Pemahaman Laboran tentang POS sebesar $82,8 \%$ dengan POS mengenai Sarana dan Prasarana Laboratorium sebesar $64,7 \%$.

\section{Saran}

Berdasarkan kesimpulan diatas dapat dikemukakan saran-saran sebagai berikut :

1. Perlunya peningkatan pelaksanaan POS khususnya Sarana dan Prasarana di Laboratorium Teknik Sipil UNJ karena telah mendapatkan sertifikasi manajemen mutu ISO 9001:2008 dan IWA 2:2007.

2. Adanya perbaikan untuk peningkatan pelaksanaan 4 POS mengenai Sarana dan 
Prasarana Laboratorium Teknik Sipil UNJ agar dapat pencapaian $100 \%$.

3. Perbaikan yang paling besar dilakukan adalah di POS mengenai peminjaman peralatan Laboratorium serta POS mengenai pemeliharaan dan perawatan Laboratorium dan Alat Laboratorium di 5 Laboratorium yang ada di Teknik Sipil UNJ.

4. Dibutuhkan dorongan untuk memotivasi para Laboran yang ada di 5 Laboratorium untuk mengerti pentingnya pelaksanaan POS. Serta memberikan motivasi agar Laboran memiliki rasa tanggung jawab dan kepedulian yang tinggi terhadap Laboratorium yang mereka kelola.

5. Perlunya peningkatan koordinasi antara Ketua Koordinator Laboratorium, Ketua Unit Laboratorium, Dosen, serta Laboran.

6. Adanya penelitian lebih lanjut dapat menyelesaikan masalah yang terjadi dalam kinerja Laboran di 5 Laboratorium.

\section{DAFTAR PUSTAKA}

Abu-Elwan, R. 2000. Effectiveness of Problem Posing Strategies on Perspective Mathematics Teachers' Problem Solving Performance. (Online) Tersedia http://math.unipa.it/ grim/AAbuElwan16. (7 September 2007)

Arikunto, Suharsimi. 2006. Prosedur Penelitian : Suatu Pendekatan Praktik. Jakarta: Rineka Cipta.
BSN. 2010. Standar Manajemen Mutu. Jakarta : Badan Standarisasi Nasional.

Hadis, Abdul \& Nurhayati. 2010. Manajemen Mutu Pendidikan. Bandung : AlfaBeta.

Moenir. 1992. Manajemen Pelayanan Umum di Indonesia. Jakarta : Bumi Aksara.

Mulyasa. 2004. Manajemen Berbasis Sekolah. Bandung : PT. Remaja Rosdakarya.

Nasution. 2001. Manajemen Mutu Terpadu. Jakarta : Ghalia Indonesia.

Sugiyono. 2011. Metode Penelitian Kuantitatif, Kualitatif, dan R\&D. Bandung : Alfabeta

SGS. 2010. Interpretation of ISO 9001 : 2008 \& Internasional Workshop Agreement (IWA) - 2 : 2007. Jakarta : SGS

SGS. 2010. Rancangan Pedoman Standarisasi Nasional IWA 2 : 2007.Jakarta : SGS.

Sena. 2011. Instrumen penelitian dan tekniknya. http://rumah-blogbaca.blogspot.com/2011/07/instrumenpenelitian-dan-teknnik.html (diakses 12 juli 2013)

Solihin. 2012. Metode penelitian. http://asepsolihin.blogspot.com/2012/11/metodepenelitian_2.html (diakses 12 juli 2013)

UNJ. 2011. Standard Operating Procedure Sarana, Prasarana, dan Sistem Informasi. Jakarta : Fakultas Teknik Universitas Negeri Jakarta.

Wirahatnala. 2013. Pengertian angekt atau kuesioner.

http://ssbelajar.blogspot.com/2012/11 langket-atau-kuesionerquestionaire.html (diakses 12 juli 2013 